\title{
NEW DISTRIBUTIONAL RECORDS FOR THE RARE MEXICAN PITVIPER CERROPHIDION PETLALCALENSIS (SOUAMATA: VIPERIDAE) FROM VERACRUZ AND OAXACA, MÉXICO, WITH COMMENTS ON DISTRIBUTION AND THE NATURAL HISTORY. NUEVOS REGISTROS DE DISTRIBUCIÓN PARA EL VIPÉRIDO RARO CERROPHIDION PETLALCALENSIS (SQUAMATA: VIPERIDAE) DE VERACRUZ Y OAXACA, MÉXICO, CON COMENTARIOS SOBRE SU DISTRIBUCIÓN E HISTORIA NATURAL
}

\author{
Miguel A. De la Torre-Loranca르. Christoph Imre Grünwald², Antonio Esau Valdenegro-Brito ${ }^{3,4}$, \\ ROMINA ITZE L CERVANTES-BURGOS ${ }^{3,4}$ AND URI OMAR GARCÍA-VÁZQUEZ ${ }^{3 * *}$ \\ ${ }^{1}$ Instituto Lorancai. Km 32 Carretera Federal Orizaba-Zongolica, Ocotepec, Los Reyes, Veracruz, México. C.P.95000. \\ ${ }^{2}$ Biodiversa A. C., Avenida de la Ribera \#203, C.P. 45900, Chapala, Jalisco, Mexico. \\ ${ }^{3}$ Laboratorio de Sistemática Molecular, Unidad de Investigación Experimental Zaragoza, Facultad de Estudios Superiores Zaragoza, Universidad \\ Nacional Autónoma de México, Batalla 5 de mayo s/n, Col. Ejército de Oriente, 09230, CDMX, México. \\ ${ }^{4}$ Posgrado en Ciencias Biológicas, Centro Tlaxcala Biología de la Conducta. Universidad Autónoma de Tlaxcala, Carretera Tlaxcala-Puebla Km. 1.5, \\ La Loma Xicohténcatl, 90070, Tlax. México. \\ "Correspondence: urigarcia@gmail.com
}

Resumen.- A partir del trabajo de campo aumentamos la distribución conocida de Cerrophidion petlalcalensis, una víbora de foseta endémica de México cuya distribución fue subestimada durante muchos años. Reportamos esta especie por primera vez para el estado de Oaxaca, y presentamos datos de historia natural y la distribución potencial de la especie a partir de nuestras observaciones. Finalmente discutimos la conservación potencial de esta especie.

Palabras clave.-Cerrophidion petlalcalensis, conservación, distribución, historia natural, endemismo.

Abstract.- Based on field work we extend the known distribution of Cerrophidion petlalcalensis, an endemic pitviper from Mexico whose distribution was underestimated for many years. We report this species from Oaxaca for the first time, and we discuss natural history data and potential distribution of the specie based on our observations. Finally we discuss potential conservation actions for this species.

Keywords.- Cerrophidion petlalcalensis, conservation, distribution, endemism.

The five species of Cerrophidion are distributed in neotropical montane habitats between 1200-3500 masl from Veracruz, Mexico to central Panama (Campbell \& Lamar, 2004). Three species occur in Mexico, of which Cerrophidion godmani Günther 1863 is the most widespread. Cerrophidion petlalcalensis LópezLuna, Vogt \& de la Torre Loranca 1999 and Cerrophidion tzotzilorum
Campbell 1985 have restricted geographical ranges and are endemic to Mexico (López-Luna et al., 1999; Campbell \& Lamar, 2004; Jadin et al., 2012). Cerrophidion petlalcalensis is characterized as a small and moderately stout pitviper with a dorsal pattern of dark brown blotches usually forming a zigzag band; a deep pit in front the eye; the dorsal ground color is medium brown, grayish 
brown or reddish brown; the sides of the head below and anterior to the postorbital stripe are pale brown or pinkish cream; a small white edged, dark brown subocular spot involves two supralabial scales; scales on top of head variable; usually with conspicuously enlarged frontal and parietal plates; dorsal scales keeled and in 19 rows at midbody, subcaudals undivided (Campbell \& Lamar, 2004). C. petlalcalensis is the species of the genus with the northernmost distribution, and is known from five specimens collected from Cerro Petlalcala, Municipality of San Andrés Tenejapan, in the Sierra de Zongolica region of Veracruz (LópezLuna et al., 1999). This species has been reported from pine-oak woodland between 2000-2500 m asl (López-Luna et al., 1999). The Sierra de Zongolica is located in the west-central part of Veracruz and its herpetofauna is one of the least studied in the country where the herpetological biogeography and diversity is all but unknown (Canseco-Márquez et al., 2016).

We conducted field work to survey the true distribution of $C$. petlalcalensis from 2011 through 2018. Numerous localities were sampled in the Sierra de Zongolica of Veracruz, the Sierra Negra of Puebla and the region known as Sierra Mazateca or Sierra de Huáutla de Jiménez of Oaxaca. While known by different names in the three different states, all these areas compose the same general geographical area, which is a mountain mass pertaining to the Sierra Madre Oriental of eastern Mexico, and with continuous elevations above 2000 masl stretching from the Municipality of Orizaba, Veracruz south to the Municipality of Mazatlán Villa de Flores in Oaxaca. Grünwald et al. (2015) recognized two geographical formations with this area, and referred to the northern region as the Biogeographical Formation \#30 (Veracruzan Sierra Madre Oriental Pine-oak Woodland) and they referred to the southern region as Biogeographical Formation \#31 (Mazatecan Sierra Madre Oriental Pine-oak Woodland).

Additionally, we applied the maximum entropy method (Maxent; Phillips et al., 2006), to perform ecological niche modeling (ENM) in order to obtain a species distribution

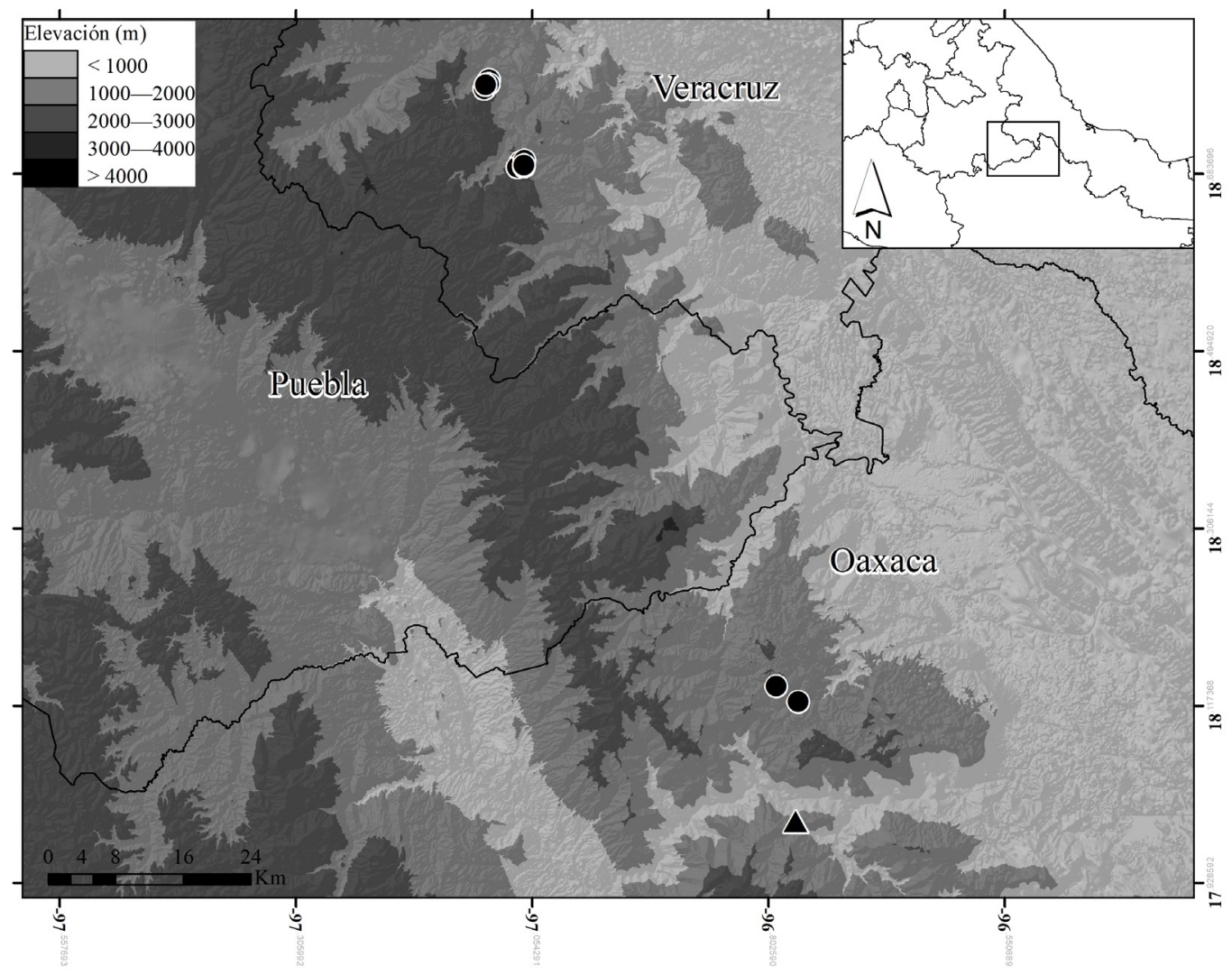

Figura 1. Distribución geográfica de Cerrophidion petlalcalensis. Los círculos negros representan los registros de la especie, y el triángulo negro representa un espécimen no determinado de Cerrophidion.

Figure 1. Geographic distribution of Cerrophidion petlalcalensis. The black circles represent the records of the species, and the black triangle represents an unidentified specimen of Cerrophidion. 

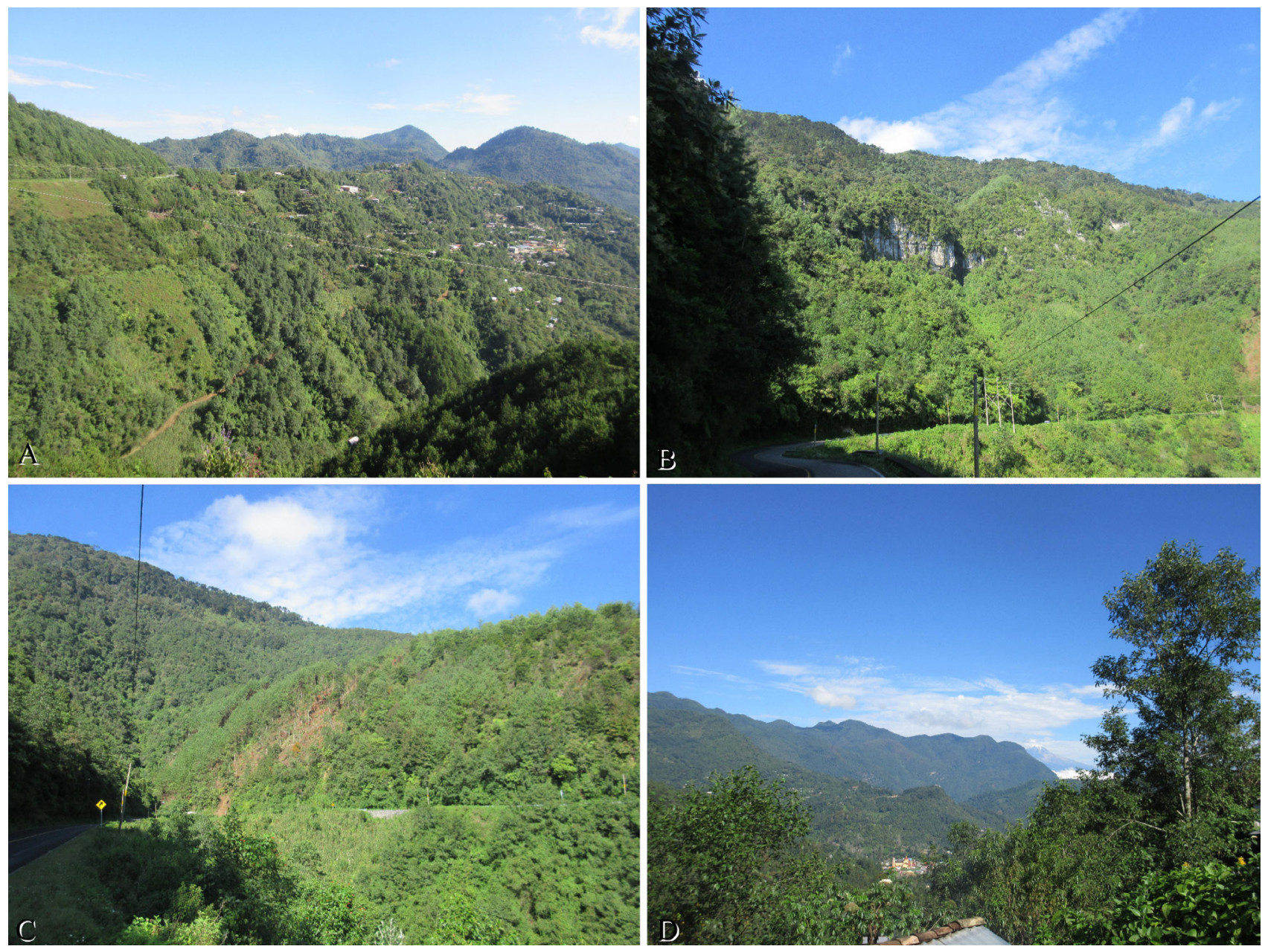

Figura 2. Hábitat típico de Cerrophidion petlalcalensis. A y B) Atlanca, Municipio de Los Reyes, Veracruz. C) Koyomitla, Municipio de Tequila, Veracruz. D) Cerro Petlalcala, Municipio de San Andrés Tenejapan, Veracruz

Figure 2. Typical habitat of Cerrophidion petlalcalensis. A y B) Atlanca, Municipality of Los Reyes, Veracruz. C) Koyomitla, Municipality of Tequila, Veracruz. D) Cerro Petlalcala, Municipality of San Andrés Tenejapan, Veracruz.

model (SDM). All environmental variables were resampled to an oblique Mercator projection at $1 \mathrm{~km}^{2}$ resolution. Subsequently a correlation of variables was made to discard those that did not provide any bioclimatic information. Two temperature variables and three precipitation variables (Isothermality, minimum temperature coldest month, precipitation seasonality, precipitation of driest quarter, precipitation of driest month, precipitation of coldest quarter and precipitation of wettest quarter) were extracted from the WorldClim (Fick \& Hijmans, 2017) data set. They were used as parameters random test $25 \%$; replicated run type: subsample and apply threshold rule: minimum training presence. We evaluated the model with the receiver operating characteristics (ROC) curve which I throw a value of area under curve (AUC $=0.984$ ). The environmental variables with high percent contribution are precipitation seasonality (32.1\%) and minimum temperature coldest month (32.4\%).

The specimens collected during this study were deposited to the Colección de Herpetología de la Facultad de Ciencias Biológicas de la Universidad Juárez del Estado de Durango (CHFCB), the Colección de Herpetología del Museo de Zoología, Facultad de Estudios Superiores Zaragoza, UNAM (MZFZ), and the Colección de Anfibios y Reptiles del Instituto Tecnológico Superior de Zongolica (ITSZ). In the event individuals were observed but not collected, digital photographs were submitted to the Colección Digital de Vertebrados de la Facultad de Estudios Superiores Zaragoza, UNAM (MZFZ-IMG). Fieldwork 
was conducted under the authority of collecting permit FAUT 0243 issued to Uri O. García-Vázquez by the Secretaría de Medio Ambiente y Recursos Naturales. The Snout-vent Length is abbreviated SVL and Total Length is abbreviated TL throughout.

\section{Geographical distribution}

During our field work we recorded 29 individual of $C$. petlalcalensis from five municipalities in Veracruz and Oaxaca (Fig. 1, Appendix 1). Amongst these observations is the first record of $C$. petlalcalensis for the state of Oaxaca, and we extend the known distribution for the species in the state of Veracruz. Furthermore, we report photographic evidence of two additional records of Cerrophidion from the state of Oaxaca. The photographs confirm without a doubt the presence of the genus in the state of Oaxaca, however it is impossible to determine definitely which species of Cerrophidion they represent.

Veracruz. - From the state C. petlalcalensis was known only from the type locality, Cerro Petlalcala, in the Municipality of San Andrés Tenejapan. Hereby we report five additional records from the type locality. Furthermore, we report 5 records from Municipality of Atlahuilco, 13 records from Municipality of Los Reyes, and 5 records from Municipality of Tequila. These records are the first records for each of these municipalities, and also represent range extensions from the type locality of $7.5 \mathrm{~km}, 9.0$ $\mathrm{km}$ and $12.0 \mathrm{~km}$ to the SW, S, and SE respectively.

Oaxaca. - From the state of Oaxaca we report two records of $C$. petlalcalensis from the Municipality of Huátla de Jiménez. Both records are from the same immediate vicinity of San Andrés Hidalgo, at elevations of 1494 and $1785 \mathrm{~m}$ a.s.l. These records represent the first of this species from both the municipality and the state. Furthermore, the record at $1494 \mathrm{~m}$ asl represents the lowest known elevation from which this species has been recorded (López-Luna et al., 1999).

We report two additional photographic records of Cerrophidion from Oaxaca of particular interest. Unfortunately it is impossible to definitely assign these records to a species based solely on photographs, and no specimens or tissue were collected. One record is from the community of El Tocón, in

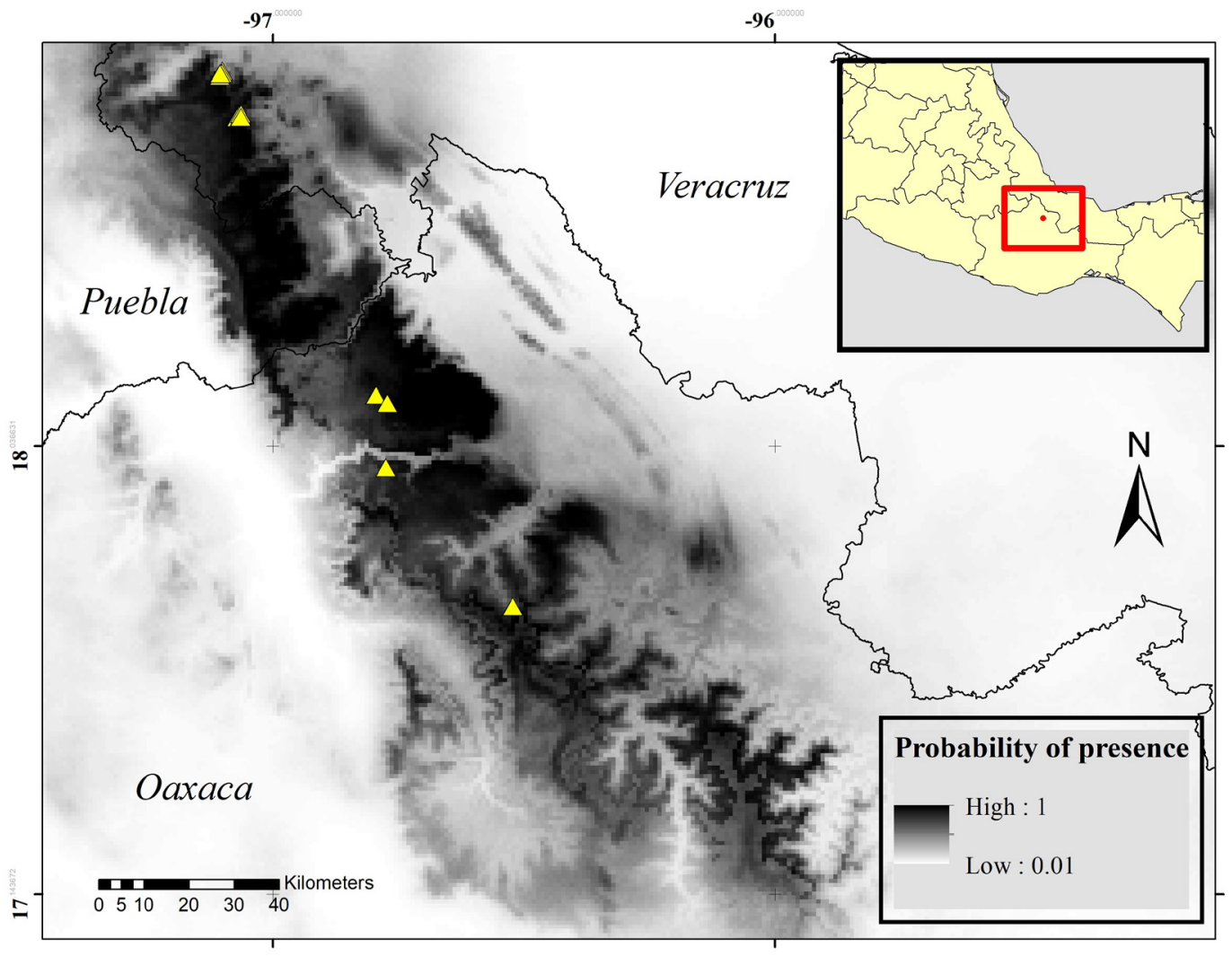

Figura 3. Modelo de distribución de C. petlalcalensis. Los triángulos amarillos representan los registros de presencia.

Figure 3. Species distribution model of $C$. petlalcalensis. Triangles yellow represent presence records. 
Tabla 1. Datos cuantitativos de los neonatos de Cerrophidion petlalcalensis..

Table 1. Quantitive data of neonates of Cerrophidion petlalcalensis.

\begin{tabular}{cccccc}
\hline Number & TL $(\mathbf{c m})$ & Weigth $(\mathbf{g})$ & Number & TL $(\mathbf{c m})$ & Weigth $(\mathbf{g})$ \\
\hline MZFZ-IMG-212 & 16 & 4 & MZFZ-IMG-219 & 18.6 & 6 \\
MZFZ-IMG-213 & 16.2 & 4 & MZFZ-IMG-220 & 18.5 & 6 \\
MZFZ-IMG-214 & 15.9 & 4 & MZFZ-IMG-221 & 18.6 & 6 \\
MZFZ-IMG-215 & 15.5 & 3 & MZFZ-IMG-222 & 18.4 & 6 \\
MZFZ-IMG-216 & 16.2 & 4 & & & \\
MZFZ-IMG-217 & 16 & 4 & & & \\
MZFZ-IMG-218 & 14.3 & 2 & Mean = 18.5 & Mean $=\mathbf{6}$ \\
& Mean $=\mathbf{1 5 . 7}$ & Mean $=\mathbf{3 . 6}$ & & & \\
\hline
\end{tabular}

Municipality of Chiquihuitlán de Juárez. This locality is within the Sierra Monteflor, an isolated mountain range between Sierra Mazateca and the Sierra Juárez to the south. This record is significant as it is south of the Río Santo Domingo barranca which presents low elevations that were considered formidable barriers for montane pitviper dispersal (Grünwald et al., 2015).

Habitat. - Unlike the type locality where C. petlalcalensis has been reported from pine-oak woodland, the new records from Veracruz reported herein are come from montane cloud forest (Fig. 2). According to Castillo-Hernández and Flores-Olvera (2017) the cloud forest in the Sierra de Zongolica is composed of at least 401 species of plants pertaining to 272 genera and 102 families. Orchidaceae, Asteraceae, Fabaceae and Piperacea are the most diverse families, whereas the genera Peperomia, Tillandsia, Polypodium, Quercus, and Solanum are the most speciose in the area.

\section{Niche modeling}

Cerrophidion petlancanensis presents affinity to the combination of low temperatures with high precipitation that corresponding to mesophilic montane cloud forests. According to the species ecological niche model (ENM) and distribution model (SDM), it might be possible to find the species in the mountains of central Veracruz, southern Puebla and northern Oaxaca; however in Puebla state the species has not yet been registered (Fig. 3).

\section{Natural history}

The 29 records reported herein has increased the known individuals of C. petlalcalensis by eightfold, and allowed us to collect some natural history data.

Reproduction. - A gravid female (MZFZ-IMG-223) which was maintained alive in captivity gave birth to seven live neonates on 09 August 2018. The female had a SVL $420 \mathrm{~mm}$, weighed $61 \mathrm{~g}$ before giving birth and $47 \mathrm{~g}$ after. The neonates had an average TL of $157 \mathrm{~mm}$ and weighed an average of $3.5 \mathrm{~g}$ (Table 1, Fig. 4a). A second gravid female (MZFZ-IMG- 208) was maintained alive in captivity and gave birth to four live neonates on 17 September 2018. The female had a SVL of $440 \mathrm{~mm}$, and weighed $63 \mathrm{~g}$ before giving birth and $31 \mathrm{~g}$ after. The neonates had an average TL of $185 \mathrm{~mm}$ and weighed an average of $6.0 \mathrm{~g}$ (Table 1, Fig. 4b). Upon comparing both litters, the smaller litter had consisted of larger neonates. One neonate, (MZFC-IMG-192) (Fig. 4c) was born alive with a birth deformation of the head lacking both eyes and both pits. In the field, we observed neonates from May through September.

Behavior and activity. - With the exception of individuals encountered on the highway, most individuals were found on the ground partially concealed amongst vegetation in the evening between $20: 00$ and 24:00 hrs. Upon disturbance, individuals displayed aggressive behavior, consisting of rapid movement of the tail while continuously striking. Several individuals were found at the base of rocky cliffs during early morning (7:0010:00 hrs) basking in sunlight. Based on our observations and those reported in literature (López-Luna et al., 1999) this species presents predominately crepuscular and nocturnal activity as long as the climate permits it. Juveniles and neonates have yellowish coloration on their tail (Fig. 4d). In other neotropical pitviper species, such as species in the genus Bothrops, this tail coloration has been theorized to lure (Green, 2000). Based on 

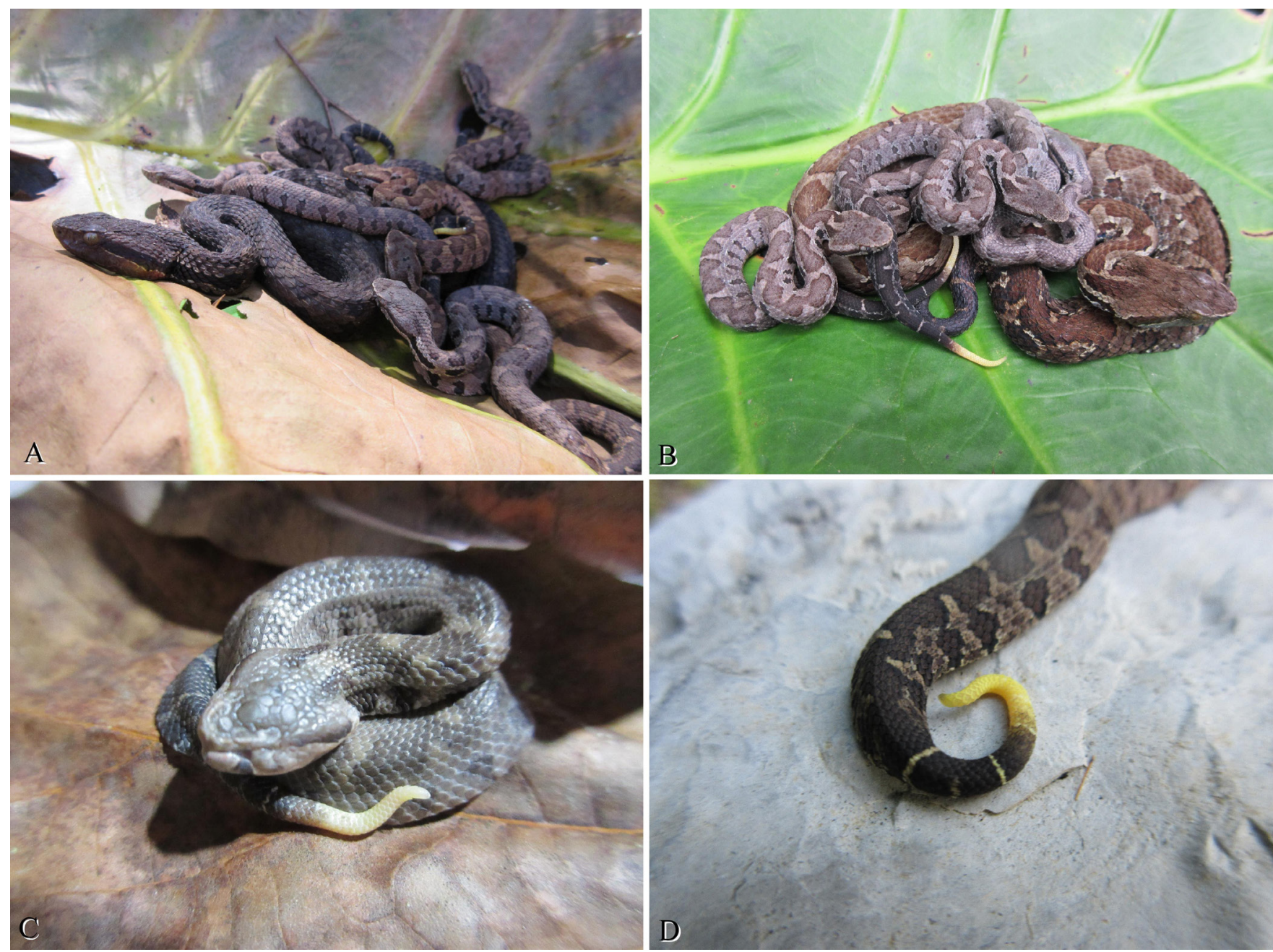

Figura 4. Cerrophidion petlalcalensis. A) Hembra con neonatos (MZFZ-IMG-223). B) Hembra con neonatos (MZFZ-IMG-208). C) Neonato con deformación de nacimiento (MZFZ-IMG-2017). D) Coloración de cola en neonato.

Figure 4. Cerrophidion petlalcalensis. A) Female with neonates (MZFZ-IMG-198). B) Female with neonates (MZFZ-IMG-183). C) Neonate with birth deformation (MZFZ-IMG-192). D) Juvenile tail coloration on neonate.

our observations, the primary activity period of this species is between June and August, and activity the rest of the year appears to be sporadic.

\section{Conservation}

Currnetly Cerrophidion petlalcalensis is not protected by the Mexican government (NOM-059-SEMARNAT-2010). Within the IUCN's list of threatened species it is considered as "Data Deficient" (López-Luna \& Campbell, 2007). While we extend the known distribution of this species considerably in this publication, it is important to note that the localities reported herein are experiencing severe deforestation and other forms of habitat destruction. We recommend that based on the apparent rarity of this species as well as the rampant deforestation of the cloud forests, that this species be considered for protection by both national and international conservation efforts.

Agradecimientos.- Support for field work was given to Uri O. García-Vázquez by Dirección General de Apoyo al Personal Académico, Universidad Nacional Autónoma de México (PAPIIT IN-216619). We thank Erasmo Cázares-Hernández for his assistance preserving specimens deposited to the ITSZ. We are especially grateful to Gerardo Morrill-Corona and Oscar Morales-Posada for providing data for the first records of this species from Oaxaca. Further support for fieldwork was 
provided by Herp.mx AC.

\section{CITED LITERATURE}

Campbell, J.A. 1985. A new species of highland pit viper of the genus Bothrops from southern México. Journal of Herpetology 19:48-54.

Campbell, J.A. \& W.W. Lamar. 2004. The Venomous Reptiles of the Western Hemisphere. Cornell University Press, Vol. I-II, Ithaca, N.Y.

Canseco-Márquez, L., C.J. Pavón-Vázquez, M.A. López-Luna \& A. Nieto-Montes de Oca. 2016. A new species of earth snake (Dipsadidae, Geophis) from Mexico. ZooKeys 610: 131-145.

Castillo-Hernández, L.A \& H. Flores-Olvera. 2017. Floristic composition of the cloud forest of the Bicentenario Reserve, Zongolica, Veracruz, Mexico. Botanical Sciences 95:1-25.

Fick, S.E. \& R. J. Hijmans. 2017. WorldClim 2: new 1-km spatial resolution climate surfaces for global land areas. International Journal of Climatology 37: 4302-4315.

Greene, H.W. 2000. Snakes: The Evolution of Mystery in Nature. University of California Press. USA.

Grünwald, C.I., J.M. Jones, H. Franz-Chávez \& I.T. AhumadaCarrillo. 2015. A new species of Ophryacus (Serpentes: Viperidae: Crotalinae) from eastern Mexico, with comments on the taxonomy of related pitvipers. Mesoamerican Herpetology 2: $388-416$.

Günther, A. 1863. Third account of new species of snakes in the collection of the British Museum. Annals and Magazine of Natural History 3:348-365.

Jadin, R.C., J.H. Townsend, T.A. Castoe \& J.A. Campbell. 2012. Cryptic diversity in disjunct populations of Middle American Montane Pitvipers: a systematic reassessment of Cerrophidion godmani. Zoologica Scripta 41:455-470
Lopez-Luna, M.A., R.C. Vogt \& M.A. de la Torre Loranca. 1999. A new species of montane pitviper from Veracruz, México. Herpetologica 55:382-389.

Lopez-Luna, M.A. \& J.A. Campbell. 2007. Cerrophidion petlalcalensis. The IUCN Red List of Threatened Species 2007: e.T64306A12761869.

Norma Oficial Mexicana (NOM-059-SEMARNAT-2010). Protección ambiental-especies nativas de México de flora y fauna silvestresCategorías de riesgo y especificaciones para su inclusión, exclusión o cambio-Lista de especies en riesgo. Diario Oficial de la Federación Secretaria de Medio Ambiente y Recursos Naturales 30 de diciembre de 2010.

Phillips, S.J., R.P. Anderson \& R.E. Schapire, 2006. Maximum entropy modelling of species geographic distributions. Ecology Modelling 190:231-259.

Zug, G., L. Vitt \& J. Caldwell. 2001. Herpetology: an introductory biology on amphibians and reptiles. Segunda edición. Academic Press. San Diego, California, E.E.U.U.

\section{APPENDIX 1.- SPECIMENS AND RECORDS}

Cerrophidion petlalcalensis.-Oaxaca (2): Huautla de Jiménez: San Andrés Hidalgo (MZFZ-IMG-205-206, 1494-1787 m a.s.l.). Veracruz (27): Atlahuilco: Xibtla (MZFZ-IMG-208, 2019, 222 $2405 \mathrm{~m}$ a.s.l.). Los Reyes: Atlanca (MZFZ-IMG-209-217, 223225, 1897-1906 m. elev). San Andres Tenejapan: Cerro Petlalcala (MZFZ-IMG-203-204, CHFCB-236, 238-39, 2020-2300 m a.s.l.). Tequila: Koyomitla (ITSZ-R-121, 131, 161, 1836-1925 m a.s.l.); Cumbre de Tequila (MZFZ-IMG-218, 1635 m a.s.1.).

Cerrophidion sp.- Oaxaca (1): Chiquihuitlán de Benito Juárez: El Tocón (MZFZ-IMG-207, 1390 m a.s.l.). 